\title{
The Effects of Artesunate on the Haematopoietic Cells In Wistar Rats.
}

\author{
${ }^{1}$ J. V. Zirahei, ${ }^{1}$ T. W. Jacks, ${ }^{1}$ D.S. Amaza, ${ }^{1}$ A .I. Numan, ${ }^{2}$ J. T. Quagar, ${ }^{2}$ Y.A. \\ Kwabwugge, ${ }^{1}$ F. Chiroma. \\ ${ }^{1}$ Department Of Human Anatomy, College Of Medical Sciences, University Of Maiduguri, P.M.B. 1069, \\ Maiduguri, Nigeria. \\ ${ }^{2}$ Department of Animal Sciences, College of Agriculture Ganye, Adamawa State, Nigeria.
}

\begin{abstract}
Twenty adult Wistar rats (18 weeks old) of both sexes (10males and 10 females) with the average weight of 118-132g were obtained and randomly assigned into four groups $(A, B, C$, and $D)$ of five rats each. Group A served as the control and was given equal volume of feeds and water ad libitum, throughout the course of the experiment. Group B which serves as the short term dose (6days) receives $4 \mathrm{mg} / \mathrm{kg} /$ day of Artesunate for 5 days and then sacrificed on the $6^{\text {th }}$ day. Group $C$ served as the medium term dose (9days), were given $4 \mathrm{mg} / \mathrm{kg}$ of Artesunate on the $1^{\text {st }}$ day and $2 \mathrm{mg} / \mathrm{kg} /$ day for 8 days and then sacrificed on the $10^{\text {th }}$ day. Group D served as the long term group (12days), received $4 \mathrm{mg} / \mathrm{kg} /$ day of Artesunate on the $1^{\text {st }}$ day and $2 \mathrm{mg} / \mathrm{kg} / \mathrm{day}$ for 12 days and then sacrificed on the $14^{\text {th }}$ day. All the rats were treated concurrently. The bone (femur) were removed and prepared for histological studies using standard $H \& E$ staining procedure. The result showed wide spread of fatty cells leading to depletion of haematopoietic cells at medium and long term doses. At these doses the process of haematopoiesis might have been altered probably by inhibiting their intracellular activities. During short term dose the effects were mild.
\end{abstract}

Keyword: Bone, Depletion, Haematopoiesis

\section{Introduction}

Malaria is a leading course of mortality and morbidity in the developing parts of the world and remains a major public health problem in this part of the world [1].

Artesunate is isolated from Chinese herb qinghao (artemisia annua) that has traditionally been used in china for the treatment of malaria [2]. It has been used against multi-drug resistant strains of plasmodium falciparum [3]; [4]. This promising anti-malaria drug has proven exceedingly useful when combined with other anti-malaria for the first-line treatment of malaria [5]. It has the highest treatment success, with lower incidence of adverse effects, and it is better tolerated than quinidine, and not hampered by accessibility issues, [6].

Artesunate had been found to bind the human plasma protein which relate to its powerful antimalarial activity [7]. Despite the beneficial effects of the drug Artesunate, cases of toxicity had been reported [8][9][10][11]. It was also found to have showed a significant increase and weight loss in high dose in experimental animals [12]. In view of the foregoing, this work was designed to determine the effect of artesunate on the haematopoietic cells in adult Wistar rat.

\section{Methodology}

Twenty adult Wistar rats(18 weeks old) of both sexes (10males and 10 females) with the average weight of $118-132 \mathrm{~g}$ were obtained and randomly assigned into four groups (A, B, C, and D) of five rats each. They were acclimatized in the laboratory for seven days and were fed with growers mash (vital feeds) obtained from grand cereals and oil mills limited, a subsidiary of UACN (Ingredients: protein $-14.50 \%$, Fat $-7.00 \%$, Crude fiber $-7.20 \%$,Calcium - $0.80 \%$, Phosphorus $-0.40 \%$, Metabolizable energy $-2500 \mathrm{kCal} / \mathrm{kg}$.) and water $\mathrm{ad}$ libitum. Artesunate were given through oral intubation.

Group A served as the control and was given equal volume of feeds and water ad libitum throughout the course of the experiment. Group B served as the short term dose (6days), received $4 \mathrm{mg} / \mathrm{kg} / \mathrm{day}$ of Artesunate for 5 days and then sacrificed on the $6^{\text {th }}$ day. Group $C$ served as the medium term dose (9days), were given $4 \mathrm{mg} / \mathrm{kg}$ of Artesunate on the $1^{\text {st }}$ day and $2 \mathrm{mg} / \mathrm{kg} /$ day for 8 days and then sacrificed on the $10^{\text {th }}$ day. Group D served as the long term group (12days), received $4 \mathrm{mg} / \mathrm{kg} /$ day of Artesunate on the $1^{\text {st }}$ day and $2 \mathrm{mg} / \mathrm{kg} /$ day for 12 days and then sacrificed on the $14^{\text {th }}$ day. The tissue were dehydrated in an ascending grade of alcohol (ethanol), cleared in xylene and embedded in paraffin wax. Serial sections of 7 microns thick were obtained using a rotatory microtome. The deparaffinised sections were stained routinely with haematoxyline and eosin. The tissue longitudinal sections were examined under the light microscope. 


\section{Results}

The bone marrow of the control group showed numerous haemopoietic cells (HC), a well defined compact bone (CB) with osteocytes (arrow), (fig.1).

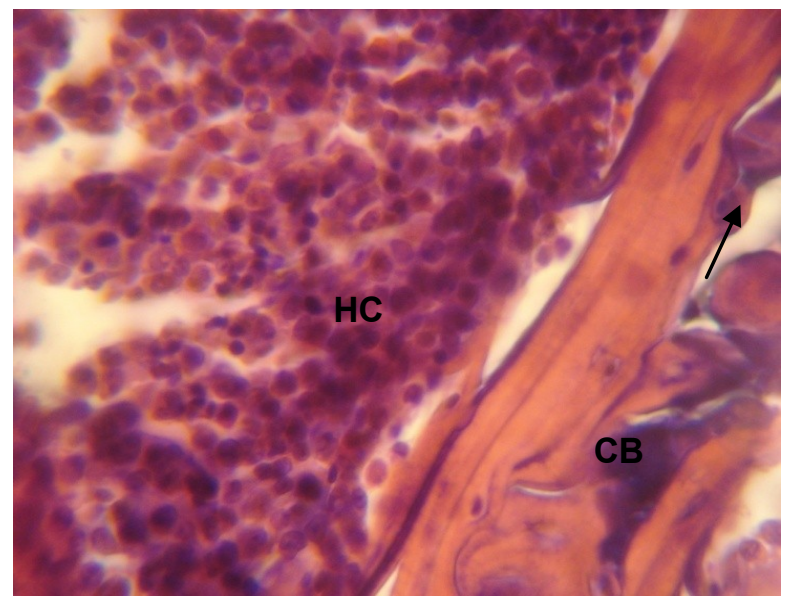

Fig. 1: Haemotopoitic cells (HC) in normal control group, H\&E x400.

The short term dose treated with $4 \mathrm{mg} / \mathrm{kg} /$ day of Artesunate for 5 days, showed wide spread of degenerating haematopoietic cells (DHC) with appearance of fatty cells (FC) in some parts of the haematopoietic system (fig. II).

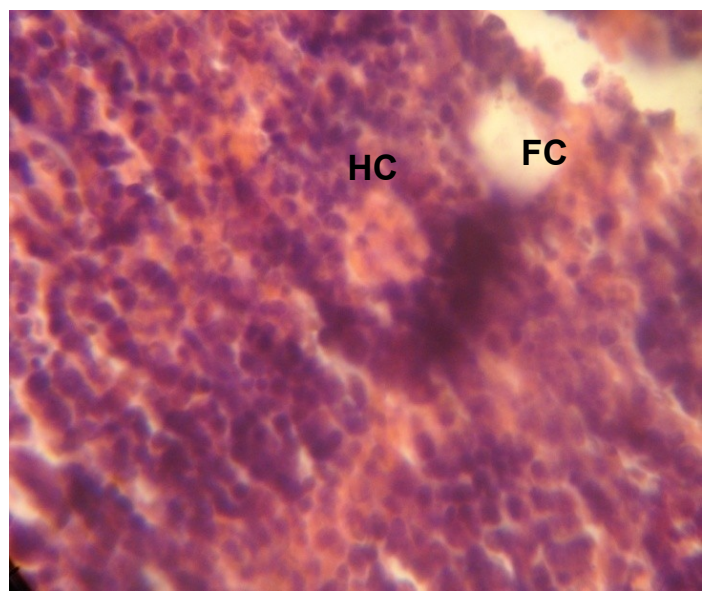

Fig. II: Section of Haematopoietic system from short term dose group in rat H \& E x 400

There were serious degeneraion of the haematopoirtic cells (HC) in the group treated with $4 \mathrm{mg} / \mathrm{kg}$ of Artesunate on the $1^{\text {st }}$ day and $2 \mathrm{mg} / \mathrm{kg} /$ day for 8 days (medium term dose), fig. III.

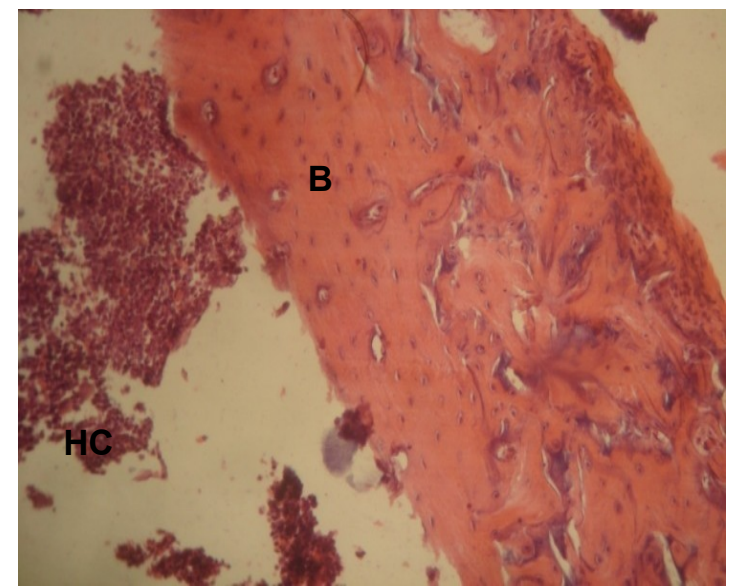

Fig. III: Section of Haematopoietic system from medium term dose group in rat, H\&E x400. 
In the long term dose, treated with $4 \mathrm{mg} / \mathrm{kg} /$ day of Artesunate on the $1^{\text {st }}$ day and $2 \mathrm{mg} / \mathrm{kg} / \mathrm{day}$ for 12 days there were complete depletion of haematopoietic cells (HC).

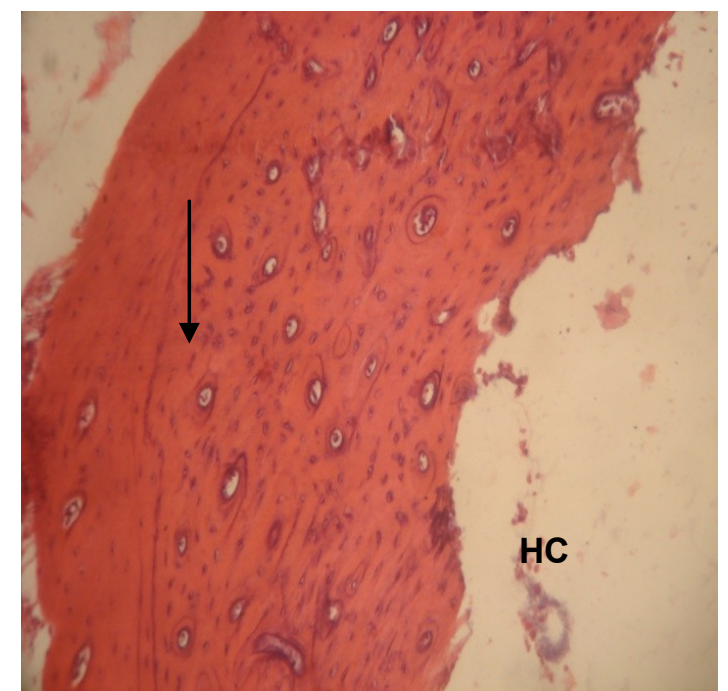

Fig. IV Section of Haematopoietic system from long term dose group in rat, H\&E x400

\section{Discussion}

Artesunate has been found to be well tolerated and efficacious, [13](Tietche et al, 2010). The use of this drug should be controlled and restricted to proven multi-drug resistance on severe malaria in order to preserve their efficacy [14](Mulenga, 1998). Artesunate is a potent blood agent for plasmodium falciparum compared with other available antimalarial drugs in Nigeria. However, despite its potential in malaria treatment [15]Paul et al (2008) reported that it induces apoptosis, necrosis and repair Cancer.

[16]Clark (2009) found that, in rats and monkeys, the embryonic erythroblasts are much more sensitive to artemisinins than are erythroblasts in the adult bone marrow, and that the latter are indicated by decreases in reticulocyte count.

In the present study there was a serious and complete depletion of haemtopoietic cells in adult wistar rats due to medium and long terms doses exposure to artesunate (figure III \& IV). There was also slight degeneration of haematopoitic cells noticeable with the gradual appearance of fatty (cells fig. II), these findings were in line with that of [8]Adebisi (2009) and [17]Efferth and Kaina (2010), that animal experiments show considerable toxicity upon application of artemisinins. Its action on calcification is not well known but it is possible, it might have facilitated the inhibition of calcium and the process of erythropooiesis [8](Adebisi, 2009). With this adverse effect of the Artemisinin - based treatments, particularly during medium and long term doses exposure or overdose, its usage should be taken with caution, due to its toxic effect on the haematopoeitic cells.

\section{Conclusion}

The present study demonstrated that medium and long term doses of artesunate leads to depletion of the haematopoietic cells, when the dosage was mild the effect were also mild and not noticeable but become pronounce with increase in exposure to the drug. This might be as a result of alteration in the intracellular activities of the haematopoietic cells.

\section{Acknowledgements}

The authors thank Ahmed Modu, Department of Histopathology, University of Maiduguri Teaching Hospital (UMTH); University of Maiduguri, Nigeria; for providing laboratory facilities for conducting the experiments.

\section{Competing Interests}

Authors Have Declared That No Competing Interests Exist. 


\section{References}

[1]. Breman, J.G., Alilio, M.S., Mills, A., Conquering of the intolerable burden of malaria a summary, Am Jl of tropical medicine and hygiene, 71, 2004, 1-15.

[2]. Bennett, B., Han Z., Boyle, D.L., Aupperle, K.R., Manning, A.M., Miagkov, A.V., Kovalenko, D.V., Brown, C.E., Anti-malarial agent artesunate inhibits YNF- $\alpha$-induced production of proinflammatory cytokines via inhibition of NF- $\mathrm{KB}$ and PI3 kinase/Akt signal pathway in human rheumatoid arthritis fibroblast-like synoviocytes, Acta Pharmacol Sin, 26, 2005, $1352-8$.

[3]. Batty, K.T., Ilett, K.F., Davis, T., Chemical stability of Artesunate injection and proposal for administration by intravenous infusion, J of Pharm and Pharmacol, 48, 1996, 22-26.

[4]. Price, R., Van Vugt M., Nosten, F., Luxemburger, C., Brockman, A., Phaipun, L., Chonsuphajaissiddi, T., White, N., Artesunate versus artemether for the treatment of recrudescent multi-drug resistant falciparum malaria, Am J of trop med and hyg, 59, 1998, $883-888$

[5]. Adjuik, M., Babiker, A., Garner, P., Olliaro, P., Taylor, W., White, N., International Artemisinin study group in: Artesunate combination for the treatment of Malaria, 2004, 363:9-17.

[6]. Hess M.K, Goad, J.A., Arguin, M. P., Intravenous Artesunate for the treatment of severe malaria. The annals of pharmacotherapy, 44, 2008, $7-8$.

[7]. Qigui, L., Lisa, H. X., Adam, H., Jing, Z., Peter, W., The evaluation of radiolabeled Artesunate on tissue distribution in rats and protein binding in humans. Am J Soc of trop Med and hyg, 75, 2006, $817-826$.

[8]. Adebisi, S. Samuel, The toxicity of Artesunate on bone Developments: The Wistar rat animal model of malaria treatment. Internet Journal of Parasitic Disease, 4, 2009, 7-9.

[9]. Genovese, R.F., Petras, J.M., Brewer, T.G., Artemether neurotoxicity in the absence of deficits in behavioral performance in rats. Ann. Trop. Med. and parasitol, 89, 2000, 447-9.

[10]. Nontprasert, A., Pukrittayakamee, S., Dondorp, A.M., Clemens, R., Looareesuwans, S.,White, N.J., Neuropathology toxicity of Artemisinin derivatives in a mouse model. Am J of trop med and hyg, 67, 2000, 423-429.

[11]. Anyasor, G.N., Ajayi, E., Saliu, J.A., Ajagbonna, O., Olorunsogo, O.O., Artesunate opens mitochondrial membrane permeability transition pore. Ann. Trop. Med. Public Health, 2, 2009, $37-41$.

[12]. Nwanjo H and Oze G., (2007). Acute hepatotoxity following administration of Artesunate in Guinea pigs. The Internet Journal of toxicology, 4, 2007, 23-28.

[13]. Tietche, F., David, C., Njiki K., Mina N., Djoukoue,F.M., Hatz, C., Frey, S., Frentzel, A., Trapp,S., Zielonka, R., Mueller. E.A., Tolerability and efficacy of a pediatric granule formulation of Artesunate - Mefloquine in young children from Cameroon with uncomplicated falciparum malaria. Am J Trop Med Hyg, 82, 2010, 1034 - 1040.

[14]. Mulenga, M., Facing drug resistance therapeutic option for treatment of uncomplicated plasmodium Falciparum malaria in adult Zambians. J of med. and health science, 2, 1998, $11-20$.

[15]. Paul, C. H., Elena, L., Wynand P. R., Malgorzata Z. Z., Bernd, K., Efferth T., Artesunate derived from traditional Chinese medicine induces DNA Damage and repair Cancer. Res. 68, 2008, 4347.

[16]. Clark, R.L., Embryotoxicity of the artemisinin antimalarials and potential consequences for use in women in the first trimester. Reprod Toxicl, 28, 2009, 285-96.

[17]. Efferth, T., Kaina, B., Toxicity of the antimalarial artemisinin and its dervatives. Crit Rev Toxicol, 40, $2010,405-21$. 